Mori, Y., Tanaka, A., Nakagawa, T., Amen, Y., Kuwano, Y., Tanizaki, Y., Tomokiyo, S., Shimizu, K. (2020): Isolation and quantification of the plant growth regulator 1-triacontanol from Moso bamboo (Phyllostachys pubescens) shoot skin and its compost. Agriculture and Forestry, 66 (3): 81-93.

DOI: 10.17707/AgricultForest.66.3.08

\author{
Yasuhiro MORI ${ }^{1}$, Akinobu TANAKA ${ }^{2}$, Toshinori NAKAGAWA ${ }^{2,3}$, \\ Yhiya AMEN $N^{2,4}$, Yasumitsu KUWANO ${ }^{1}$, Yufu TANIZAKI ${ }^{1}$, \\ Shota TOMOKIYO ${ }^{1}$, Kuniyoshi SHIMIZU ${ }^{2}$
}

\title{
ISOLATION AND QUANTIFICATION OF THE PLANT GROWTH REGULATOR 1-TRIACONTANOL FROM MOSO BAMBOO (Phyllostachys pubescens) SHOOT SKIN AND ITS COMPOST
}

\section{SUMMARY}

To investigate chemical uses of Moso bamboo (Phyllostachys pubescens) shoot skin, we identified the main component of non-polar solvent extracts. To this end, a white precipitate from $n$-hexane extracts was evaluated using silica-gel column chromatography. The fraction with the highest recovery showed a single spot in silica-gel thin-layer chromatography (TLC) analyses. In subsequent nuclear magnetic resonance (NMR) and electron impact-mass spectrometry (EIMS) analyses, we identified the compound in the fraction as 1-triacontanol, which is a known regulator of plant growth. In addition, gas chromatography-mass spectrometry (GC-MS) experiments showed 1-triacontanol concentrations of 13.3 and $41.7 \mathrm{ppm}$ in fresh and boiled skins, respectively. In boiled skins, 1triacontanol concentrations reached a maximum of $71.3 \mathrm{ppm}$ after 2 weeks of composting. Although concentrations gradually decreased thereafter, they remained at 19.7 ppm after compost maturation for 6 months. In a further experiment, seeds of Welsh onion were sown on absorbent cotton impregnated with authentic 1-triacontanol solutions, significant increase in hypocotyl length was observed. Due to the presence of 1-triacontanol, Moso bamboo shoot skin has potential as functional compost that promotes plant growth for agricultural uses.

Keywords: 1-triacontanol, compost, Moso bamboo shoot skin, non-polar solvent extract, Phyllostachys pubescens.

\footnotetext{
${ }^{1}$ Yasuhiro Mori, (corresponding author: drmorich@farc.pref.fukuoka.jp), Department of Biomass Utilization, Institute of Agricultural and Forest Resources, Fukuoka Agriculture and Forestry Research Center, 1438-2, Toyoda Yamamoto-machi, Kurume, Fukuoka 839-0827, JAPAN.

${ }^{2}$ Division of Sustainable Bioresources Science, Department of Agro-Environmental Sciences, Faculty of Agriculture, Graduate School of Kyushu University, Fukuoka, JAPAN.

${ }^{3}$ Department of Biological Resources Management, The University of Shiga Prefecture, Hikone, JAPAN.

${ }^{4}$ Department of Pharmacognosy, Faculty of Pharmacy, Mansoura University, Mansoura, EGYPT.

Notes: The authors declare that they have no conflicts of interest. Authorship Form signed online.

Received:26/06/2020

Accepted:23/07/2020
} 


\section{INTRODUCTION}

Bamboo shoots are a popular delicacy with a crunchy texture and pleasant taste, and are known as the King of Forest Vegetables (Chongtham et al., 2011). Annual consumption of bamboo shoots has been maintained at approximately 200,000 t for the past forty years in Japan (Forestry Agency, Ministry of Agriculture, Forestry and Fisheries, Japan, 2020). Moso bamboo (Phyllostachys pubescens) is the highest yield species of bamboo shoots in Japan (Torii and Isagi, 1997). Moso bamboo shoots are mainly available in fresh and canned forms. When harvested during winter (off-season), Moso bamboo shoots are marketed as the fresh form without peeling. Spring (peak season) harvests, however, are often processed by boiling and canning for long term storage. Boiled shoots are generally peeled prior to canning, leading to the accumulation of numerous shoot skins at canning factories during the peak season. Because they generate an unpleasant odor with decay, their disposal demands significant time and cost.

In our previous studies of Moso bamboo shoot skins, components from fresh skins were roughly divided into polar and non-polar compounds by extracting with $n$-hexane and then extracting the insoluble fractions with methanol and dichloromethane (Tanaka et al., 2011, 2013). We then examined the functions of polar solvent-extracts and isolated the compounds stigmasterol and dihydrobrassicasterol from dichloromethane-soluble fractions of methanol extracts. These compounds had antibacterial activity against Staphylococcus aureus (Tanaka et al., 2011, 2013).

Moreover, in an in vitro immunization system (Iwamoto et al., 2013), these methanol extracts suppressed immunoglobulin $\mathrm{E}$ production following stimulation by the cedar pollen antigen (Cry j 1) in human peripheral blood mononuclear cells (Tanaka, 2013). Antioxidant activities of methanol extracts were also described in oxygen radical absorption capacity assays and inhibition of melanin biosynthesis was demonstrated in cultured B-16 melanoma cells (Tanaka, 2013).

These studies collectively indicate that Moso bamboo shoot skins have functional ingredients with promise in cosmetics and other health-related products following extraction with polar solvents, such as methanol. Compounds that were extracted with the non-polar solvent $n$-hexane had limited antibacterial, antiallergic, antioxidant, and antimelanoma activities (Tanaka, 2013).

In this study, we further investigated functions of non-polar solvent extracts from Moso bamboo shoot skins by isolating major components of $n$ hexane extracts and identified the plant growth regulator 1-triacontanol (Ries et al., 1977b; Naeem et al., 2012). We also determined 1-triacontanol concentrations in composted boiled (hot water-extracted) shoot skins. Finally, we report the effects of 1-triacontanol treatments on seed germination and hypocotyl lengths of a plant species. 


\section{MATERIAL AND METHODS}

\section{Moso bamboo shoot skin and composting}

Moso bamboo (P. pubescens) shoots were harvested in Miyako or Yame, Fukuoka prefecture, Japan, and non-boiled or boiled skins were provided by Life Design Co., Ltd. (Fukuoka, Japan) or Kazue Bussan Inc. (Fukuoka, Japan). Boiled skins (about $1 \mathrm{~m}^{3}$ ) were composted in a pile on a composting platform at Fukuoka Agriculture and Forestry Research Center. The pile was turned manually every 2 weeks to maintain aerobic conditions and was watered when necessary. Samples were taken before boiling (fresh) and after 0, 1, and 2 weeks, and 2, 3, and 6 months after composting. Samples were roughly crushed into small pieces and were lyophilized after storage at $-30^{\circ} \mathrm{C}$.

Isolation and identification of the main components in $n$-hexane extracts from Moso bamboo shoot skin

Non-boiled (fresh) skins of Moso bamboo shoots were dried at room temperature and were then ground to powder. The powder $(17.8 \mathrm{~kg})$ was extracted with $72.5 \mathrm{l}$ of $n$-hexane for $48 \mathrm{~h}$. The $n$-hexane solution was then evaporated, yielding $40.1 \mathrm{~g}$ (dry weight) of extract. A $39 \mathrm{~g}$ sample of the extract was dissolved in $500 \mathrm{ml}$ of $n$-hexane by sonicating and heating. The resulting solution was stored overnight at $-20^{\circ} \mathrm{C}$ and was then decanted and the precipitated solute was purified to a yellowish crude powder.

The dissolving and decanting process was repeated until the solute was bleached and $5 \mathrm{~g}$ of white precipitate was finally obtained. Subsequently, $4 \mathrm{~g}$ of crude precipitate was applied to silica-gel column chromatography (column, $\varphi 8.0$ $\times 32.0 \mathrm{~cm}$ ) with $800 \mathrm{~g}$ of Wakogel C-200 and was eluted with $2000 \mathrm{ml}$ of $n$ hexane:ethyl acetate mixtures at ratios of 10:0, 9:1, 8:2, 7:3, 6:4, 5:5, 2.5:7.5, and $0: 10$, and then with methanol $(2000 \mathrm{ml})$. For each elution stage, $500 \mathrm{ml}$ fractions were collected, leading to a total of 36 fractions (fl-f36). Fractions were combined to form 12 fractions as follows: F1 (f1-f4, $8.1 \mathrm{mg}$ ), F2 (f5-f8, $7.2 \mathrm{mg}$ ), F3 (f9-f11, 473.7 mg), F4 (f12-f13, 641.9 mg), F5 (f14-f16, 325.0 mg), F6 (f17f19, $290.1 \mathrm{mg}$ ), F7 (f20-f21, $32.2 \mathrm{mg}$ ), F8 (f22-f24, $63.8 \mathrm{mg}$ ), F9 (f25-f28, 50.2 mg), F10 (f29-f32, $22.1 \mathrm{mg}$ ), F11 (f33-f34, $2.4 \mathrm{mg}$ ), and F12 (f35-f36, 106.1 $\mathrm{mg})$. These fractions were analyzed using silica-gel thin-layer chromatography (TLC) on silica-gel 60 F254 plates (Merck Co., Darmstadt, Germany) with $n$ hexane:ethyl acetate:acetic acid at 9:1:0.1 (F1-F3), 7:3:0.1 (F4-F8), or 6:4:0.1 (F9-F12). Spots were made visible by spraying with $10 \%$ sulfuric acid/methanol and then heating on a hot plate to $140^{\circ} \mathrm{C}$. Among fractions, F4 was recovered with the highest quantity and contained a pure compound that formed a single spot in TLC analyses.

The chemical structure of the compound was analyzed using nuclear magnetic resonance (NMR) and electron impact-mass spectrometry (EI-MS). ${ }^{1} \mathrm{H}$ and ${ }^{13} \mathrm{C}$-NMR spectra were generated on a Bruker DRX 400 NMR spectrometer (Bruker Daltonics Inc., MA, USA) using tetramethylsilane (TMS) as an internal standard for chemical shifts. Chemical shifts $(\delta)$ were expressed in ppm with 
reference to TMS resonance. EI-MS was performed using a JEOL JMS 700 spectrometer (JEOL, Japan). Organic solvents and Wakogel C-200 were purchased from Wako Pure Chemical Industries (Osaka, Japan).

\section{Chloroform extraction from Moso bamboo shoot skin}

Lyophilized samples were ground into 1-mm particles using a Wiley mill and were extracted with chloroform, because authentic 1-triacontanol (Tokyo Chemical Industry Co., Ltd., Tokyo, Japan) was more soluble in chloroform than in $n$-hexane in our preliminary tests. Ground samples (10 g) were extracted three times with $100 \mathrm{ml}$ of chloroform at room temperature with shaking at $160 \mathrm{rpm}$ for $24 \mathrm{~h}$. After dehydration with anhydrous sodium sulfate, solutions were filtered through filter paper (No. 5A, 150 mm; Toyo Roshi Kaisha, Ltd., Tokyo, Japan) and were concentrated using a rotary evaporator. Dried extracts were redissolved in chloroform to a concentration of $5 \mathrm{mg} / \mathrm{ml}$.

\section{triacontanol}

Quantitative gas chromatography-mass spectrometry analysis of 1-

Forty-microliter aliquots of $\mathrm{N}, \mathrm{O}$-bis (trimethylsilyl) trifluoroacetamide (BSTFA; Fujifilm Wako Pure Chemical Corporation, Osaka, Japan) were added to each chloroform extract $(160 \mu \mathrm{l})$, and derivatization was achieved by heating the mixtures at $60^{\circ} \mathrm{C}$ for $10 \mathrm{~min}$. Gas chromatography-mass spectrometry (GCMS) analyses were performed using an Agilent 7890A gas chromatograph (Agilent Technologies, Inc., CA, USA) equipped with an Agilent 7693A autosampler (Agilent Technologies, Inc., CA, USA) and a Agilent 5975C inert XL MSD mass selective detector (Agilent Technologies, Inc., CA, USA). Into a DB-5MS capillary column (30 m long, $0.25 \mathrm{~mm}$ inner diameter, $0.25 \mu \mathrm{m}$ film thickness; Agilent Technologies, Inc., CA, USA) in the splitless mode, $1 \mu 1$ aliquots of derivatized sample were injected. The oven temperature was operated at $40^{\circ} \mathrm{C}$ for $3 \mathrm{~min}$, and the temperature was then increased to $300^{\circ} \mathrm{C}$ at $15^{\circ} \mathrm{C} / \mathrm{min}$ and was held at this temperature for $10 \mathrm{~min}$. Helium was used as a carrier gas. Injector and detector temperatures were both $250^{\circ} \mathrm{C}$. 1-Triacontanol was identified as a trimethylsilyl derivative by comparing retention times and mass spectra with those from the NIST 08 library and an authentic compound in total ion monitoring (SCAN) mode. Ions at $\mathrm{m} / \mathrm{z} 471$ and 495 were chosen as targets for identification and quantification of 1-triacontanol in selected ion monitoring (SIM) mode, because they were the most abundant and lacked cross-interferences in mass spectra. In SIM mode, 1-triacontanol concentrations were quantified using an external standard method with a 5-point calibration curve and peak areas of authentic standards ranging from 25 to $400 \mu \mathrm{g} / \mathrm{ml}$.

\section{Plant growth test}

Solutions of authentic 1-triacontanol were adjusted to $1000 \mathrm{ppb}$ in distilled water with $0.1 \%$ Tween 20 , and were then autoclaved at $121^{\circ} \mathrm{C}$ for $20 \mathrm{~min}$. They were serially diluted to 1,10 , and $100 \mathrm{ppb}$ in distilled water. Thirty Welsh onion 
(Allium fistulosum) seeds were sown on absorbent cotton impregnated with $40 \mathrm{ml}$ of each solution using a Germination Index Kit (JPec Co., Ltd., Tokyo, Japan). After incubation for 6 days in the dark at $25^{\circ} \mathrm{C}$, germination rates and hypocotyl lengths were measured. The test was independently repeated three times.

\section{RESULTS AND DISCUSSION}

Isolation and identification of 1-triacontanol from n-hexane soluble fractions of Moso bamboo shoot skins

Silica-gel column chromatography of white precipitates from $n$-hexane extracts of fresh Moso bamboo shoot skins were collected in 12 fractions. A single spot from the fraction (F4) on TLC plates showed the highest recovery (641.9 mg) of all fractions. This spot was also detected in TLC analyses of the other four fractions (F5 to F8), with close polarities to that of F4 (data not shown). Thus, the main component of the white precipitate was isolated from $\mathrm{F} 4$ and was considered a pure compound.

The pure compound 1 was isolated as a white powder from F4 (Fig. 1). ${ }^{13} \mathrm{C}$ spectrum signals were discriminated into $\mathrm{CH}_{3}$ resonance at $\delta_{\mathrm{C}} 14.3$ and a signal due to a primary alcoholic group at $\delta_{\mathrm{C}} 63.3$ (Fig. 2). Other signals were assigned to aliphatic $\mathrm{CH}_{2}$ groups, which resonated at $\delta_{\mathrm{C}} 22.9-33.0$. These data suggested that compound 1 is an aliphatic straight chain primary alcohol. ${ }^{1} \mathrm{H}-\mathrm{NMR}$ spectrum revealed a signal at $\delta_{\mathrm{H}} 3.64(\mathrm{t}, J=6.8 \mathrm{~Hz})$, indicating a $\mathrm{CH}_{2} \mathrm{OH}$ group, and a signal at $\delta_{\mathrm{H}} 0.88\left(\mathrm{t}, J=8.0 \mathrm{~Hz}, 3 \mathrm{H}\right.$ ) for a terminal $\mathrm{CH}_{3}$ group (Fig. 3). An upfield broad signal resonated at $\delta_{\mathrm{H}} 1.25(54 \mathrm{H}, \mathrm{m})$ and was assigned to H3-H29.

The number of protons at $\delta_{\mathrm{H}} 1.25$ was assumed based on the integrated intensity of the terminal methyl at $\delta_{\mathrm{H}} 0.88$ and this was confirmed using EI-MS (Fig. 4). In the splitting pattern, a triplet peak at $\delta_{\mathrm{H}} 0.88$ was integrated for $3 \mathrm{H}$ and indicated the presence of $\mathrm{CH}_{3} \mathrm{CH}_{2}$ as a partial structure of the compound. Another triplet peak with $2 \mathrm{H}$ at $\delta_{\mathrm{H}} 3.64$ was considered to be from an $\alpha$-hydrogen adjacent to a hydroxyl group, indicating the presence of $\mathrm{CH}_{2} \mathrm{CH}_{2} \mathrm{OH}$. A broad peak with $54 \mathrm{H}$ at $\delta_{\mathrm{H}} 1.25$ and a multiplet peak with $2 \mathrm{H}$ at $\delta_{\mathrm{H}} 1.57$ indicated the presence of $\left[\mathrm{CH}_{2}\right]_{27}$ and $\mathrm{CH}_{2}$, respectively. Correlated spectroscopy spectra showed correlations between protons at $\delta_{\mathrm{H}} 0.88$ and $\delta_{\mathrm{H}} 1.25$, at $\delta_{\mathrm{H}} 1.25$ and $\delta_{\mathrm{H}}$ 1.57, and at $\delta_{\mathrm{H}} 1.57$ and $\delta_{\mathrm{H}} 3.64$ (Fig. 5).

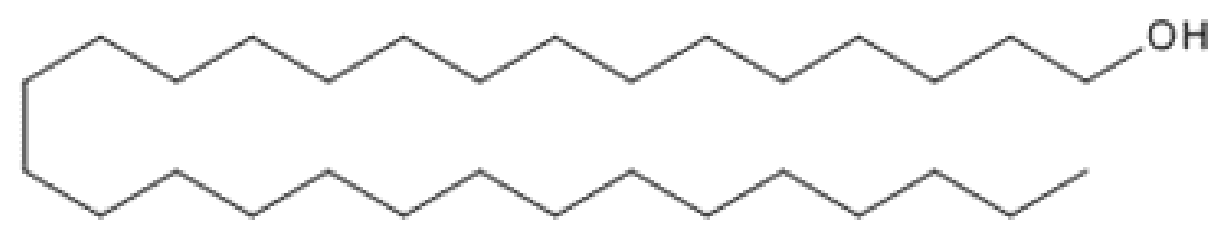

Fig. 1. Chemical structure of 1-triacontanol $\left(\mathrm{C}_{30} \mathrm{H}_{62} \mathrm{O}\right)$. 


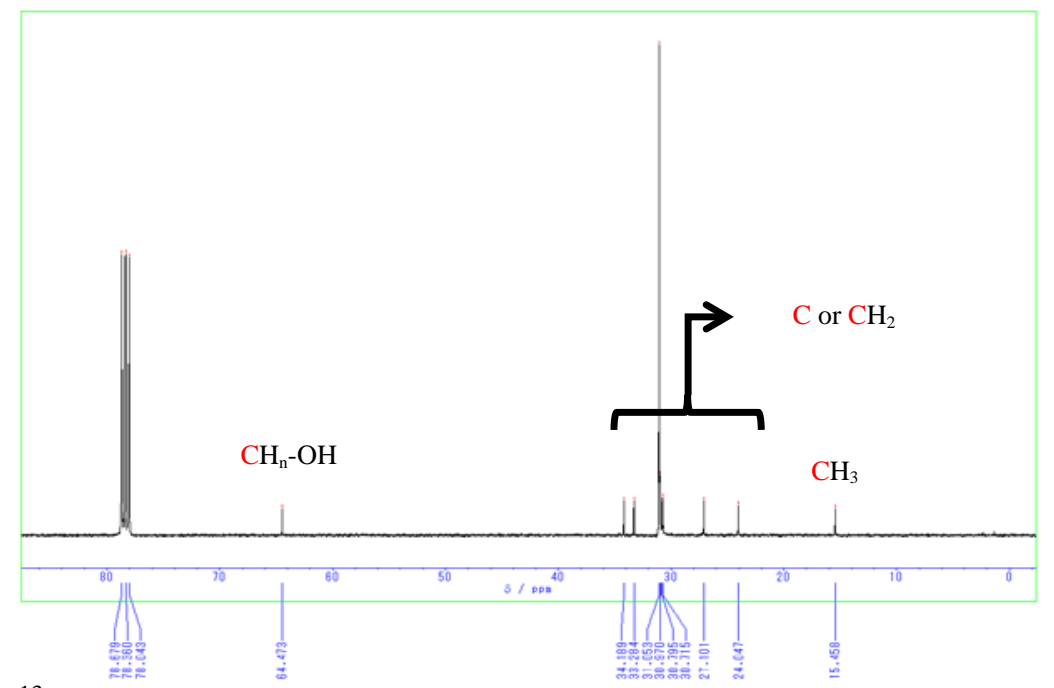

Fig. 2. ${ }^{13} \mathrm{C}$ nuclear magnetic resonance (NMR) spectra of the fraction $\mathrm{F} 4$ from $n$ hexane extracts of fresh Moso bamboo shoot skins; herein, chloroform appeared in a triplet peak with a chemical shift at $78.36 \mathrm{ppm}$. Because this value is usually $77.2 \mathrm{ppm}$, presented $\mathrm{x}$ values were adjusted by $-1.16 \mathrm{ppm}$.

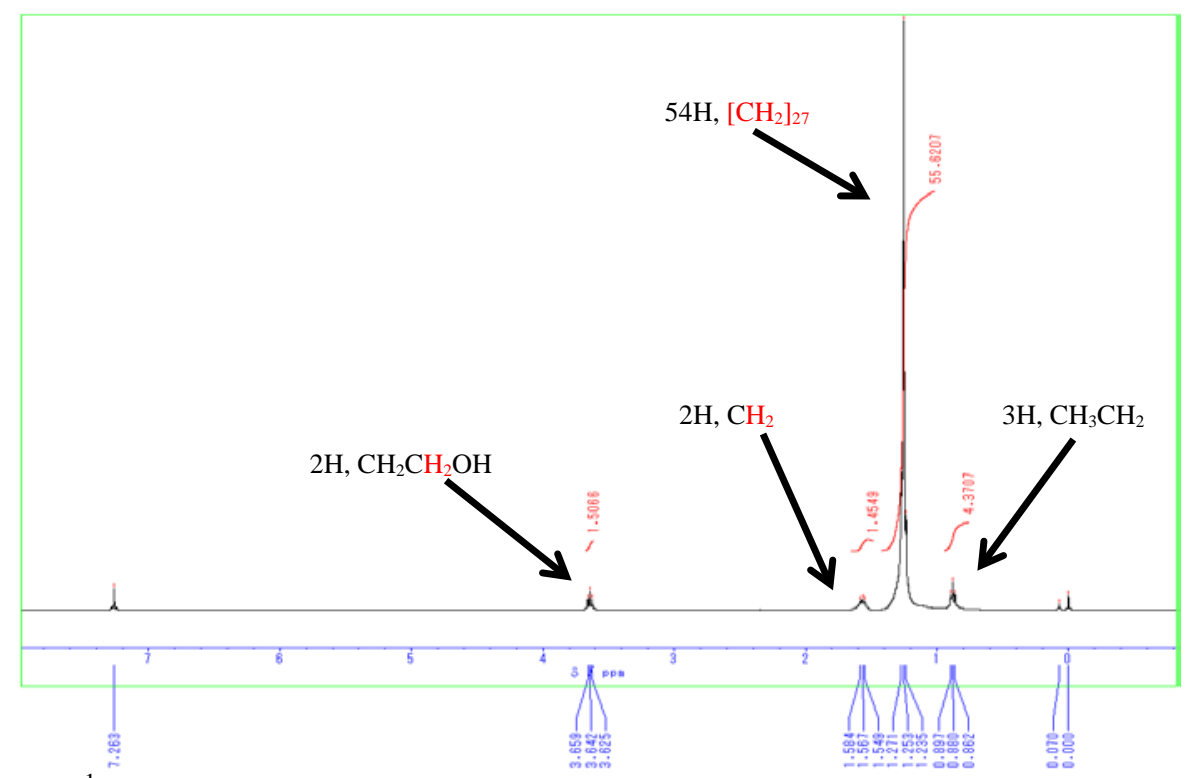

Fig. 3. ${ }^{1} \mathrm{H}$ nuclear magnetic resonance (NMR) spectra of fraction F4 of $n$-hexane extracts from fresh Moso bamboo shoot skins. 


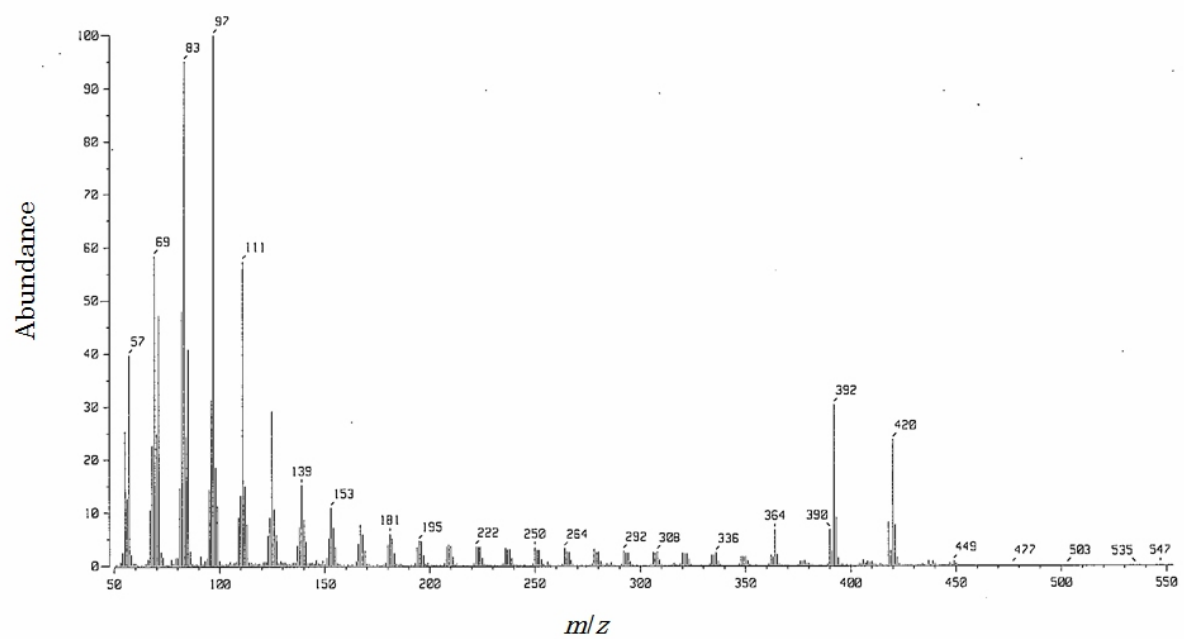

Fig. 4. Electron impact-mass spectrometry (EI-MS) of fraction F4 of $n$-hexane extracts from fresh Moso bamboo shoot skins.

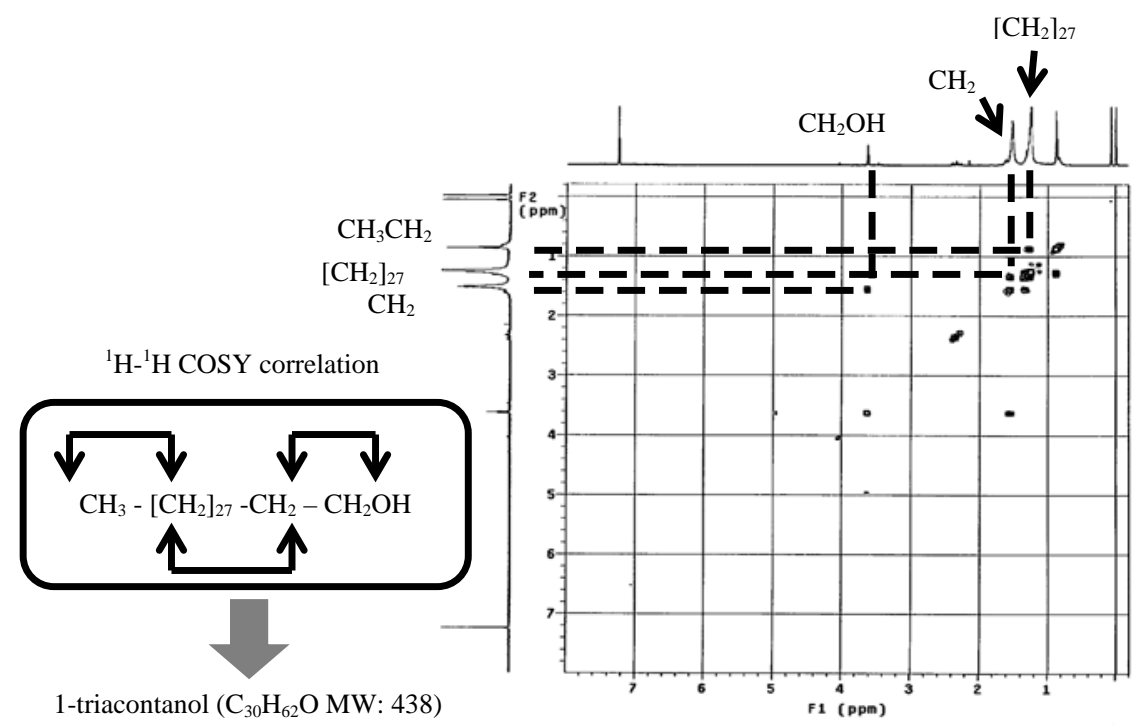

Fig. 5. ${ }^{1} \mathrm{H}-{ }^{1} \mathrm{H}$ correlated spectroscopy spectra of fraction $\mathrm{F} 4$ of $n$-hexane extracts from fresh Moso bamboo shoot skins.

Connection of the partial structures based on these correlations strongly suggested that the compound in $\mathrm{F} 4$ was 1-triacontanol. EI-MS spectra showed a base peak at $\mathrm{m} / \mathrm{z} 420\left[\mathrm{M}-\mathrm{H}_{2} \mathrm{O}\right]^{+}$, thus confirming the molecular formula $\mathrm{C}_{30} \mathrm{H}_{62} \mathrm{O}$ and the molecular weight of $438 \mathrm{~g} / \mathrm{mol}$ (Fig. 4). This base peak also supported the presence of a hydroxyl functional group in the compound. Data from NMR and EI-MS analyses of compound 1 were matched with those reported previously (Du et al., 2009; Upadhyay et al., 2006; Randrianasolo et al., 2015). Chibnall et al. 
(1931) was the first to discover 1-triacontanol, and described the compound as a constituent of apple peel wax. Subsequently, this compound was isolated from epicuticular waxes of alfalfa leaves (Chibnall et al., 1933), rice leaves (Uchiyama and Ogasawara, 1981), soybean (Glycine max) leaves (Hagedorn et al., 2017), and from sub-epidermal cells of jade plant (Crassula argentea) leaves (Kolker, 1978), potato (Solanum tuberosum) tubers (Kolker, 1978), and beeswax (Jackson and Eller, 2006). We are the first to report 1-triacontanol in Moso bamboo shoot skins. composting

Quantification of 1-triacontanol from Moso bamboo shoot skins during

Concentrations of 1-triacontanol in dry matter non-boiled (fresh) and boiled Moso bamboo shoot skins during composting are shown in Fig. 6. Before composting, boiled shoot skins contained 1-triacontanol at $41.7 \mathrm{ppm}$, more than threefold higher than in non-boiled skins $(13.3 \mathrm{ppm})$. With progress of composting, 1-triacontanol concentrations significantly increased and peaked at $71.3 \mathrm{ppm}$ after 2 weeks. Thereafter, 1-triacontanol concentrations gradually decreased to $19.7 \mathrm{ppm}$ after 6 months of composting.

According to quantitative determinations by Kolker (1978), 1-triacontanol concentrations in rice, maize (Zea mays), and alfalfa leaves were 481, 234, and $173 \mathrm{ppm}$, respectively, much higher than in fresh Moso bamboo shoot skins (13.3 ppm) and boiled skins (41.7 ppm) (Fig. 6). According to assessments from the Organization for Economic Co-operation and Development (OECD), alcohols with carbon chain lengths up to C16 are readily biodegradable, with $100 \%$ degradation in less than 10 days (OECD, 2006). In addition, alcohols with chain lengths of C16, C18, and over C18 were degraded by $62 \%, 76 \%$, and $37 \%$, respectively (OECD, 2006). In the present study, 1-triacontanol concentrations in boiled skins increased to $71.3 \mathrm{ppm}$ after 2 weeks of composting (Fig. 6). Hence, we suggest that the long chain length (C30) of 1-triacontanol may be more resistant to degradation than alcohols with shorter chain lengths. Therefore, various low-molecular weight compounds, including those from hot-water extracts, are thought to have been preferentially degraded. We observed gradual decreases in 1-triacontanol concentrations with further composting, with a remaining concentration of $19.7 \mathrm{ppm}$ at 6 months (Fig. 6). In assessments of germination rates of komatsuna (Brassica rapa var. perviridis) using Germination Index Kits, boiled skins needed 4 months for compost maturation (Tanizaki, unpublished data).

Thus, mature composts of boiled skins could be useful as functional composts, because they do not negatively affect plant growth by limiting nitrogen and contain the plant growth regulator 1-triacontanol. 


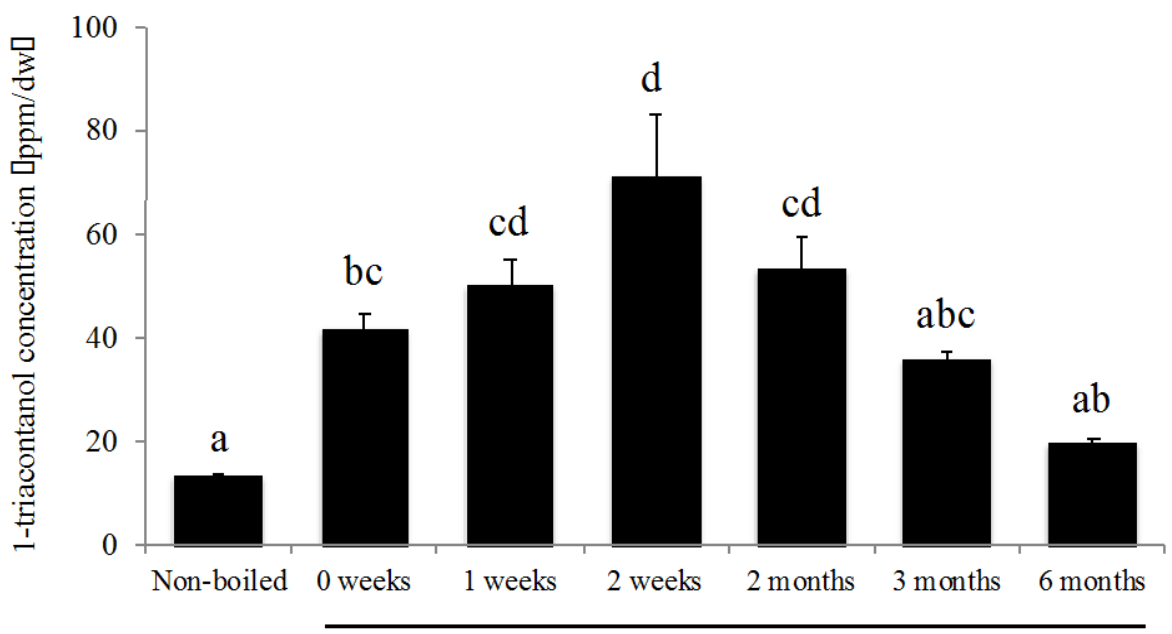

composting period of boiled skin

Fig. 6. Concentrations of 1-triacontanol in Moso bamboo shoot skins; bars indicate mean concentrations of 1-triacontanol per dry weight of skins (mean \pm SE, $n=3)$. Different lower-case letters indicate significant differences in concentrations $(p<0.05)$, as indicated by Tukey's tests.

\section{Effects of 1-triacontanol treatments on plant growth}

In this study, we monitored germination rate and hypocotyl length of Welsh onion after treatments with authentic 1-triacontanol solutions (Table 1). Germination rates of Welsh onion were over $90 \%$ in all of these treatment conditions except in the presence of $10 \mathrm{ppb}$ 1-triacontanol. Yet hypocotyl lengths of Welsh onions were significantly greater (1.25 times) in 1000 ppb 1triacontanol solution than in controls. No significant effects of 1-triacontanol treatments on Welsh onions were observed at lower concentrations.

Table 1. Germination rate and hypocotyl length of Welsh onion after treatment with authentic 1-triacontanol solutions at different concentrations

\begin{tabular}{|c|c|c|c|c|c|c|c|c|}
\hline \multirow{2}{*}{ 1-triacontanol concentration } & \multicolumn{4}{|c|}{ Germination rate (\%) } & \multicolumn{4}{|c|}{ Hypocotyl length (mm) } \\
\hline & mean & & SE & & mean & & $\mathrm{SE}$ & \\
\hline Oppb & 96.7 & \pm & 0.0 & $a b$ & 18.3 & \pm & 1.0 & $\mathrm{a}$ \\
\hline $1 \mathrm{ppb}$ & 98.9 & \pm & 1.1 & $\mathrm{a}$ & 20.1 & \pm & 0.9 & $\mathrm{ab}$ \\
\hline 10ppb & 88.9 & \pm & 2.9 & b & 17.8 & \pm & 1.2 & a \\
\hline 100ppb & 95.6 & \pm & 2.2 & $\mathrm{ab}$ & 20.3 & \pm & 0.9 & $\mathrm{ab}$ \\
\hline 1000ppb & 98.9 & \pm & 1.1 & $\mathrm{a}$ & 22.9 & \pm & 0.8 & b \\
\hline
\end{tabular}

Different lower-case letters indicate significant differences in germination rates or hypocotyl lengths (p $<0.05$ ) from Tukey's tests. 
1-Triacontanol was originally isolated from chloroform extracts of alfalfa (Medicago sativa) as a plant growth regulator that promoted water uptake and dry weight of rice (Oryza sativa, Ries et al., 1977b). According to a review article (Naeem et al., 2012), 1-triacontanol enhances growth, yield, photosynthesis, and chlorophyll contents of various plant species. When applied to shoots of rice plants, 1-triacontanol rapidly elicited biosynthesis of $9-\beta-\mathrm{L}(+)$-adenosine in the roots (Ries, 1991; Naeem et al., 2012) as a probable source, adenosine monophosphate from adenosine diphosphate and adenosine triphosphate (Olsson and Pearson, 1990; Naeem et al., 2012). Subsequently, apoplastic ion concentrations increased in plant tissues (Ries et al., 1993; Naeem et al., 2012). In published suppression subtractive hybridization and Northern blotting analyses, 1-triacontanol upregulated photosynthetic and photorespiratory genes and downregulated abscisic acid and stress- and wound-related genes (Chen et al., 2002). These events are thought to trigger various metabolic activities, including photosynthesis, nutrient uptake, and enzyme activity, likely leading to accelerated plant growth.

In this study, 1-triacontanol significantly promoted hypocotyl lengths of Welsh onion, but did not affect germination at the tested concentrations (Table 1). When micro propagated balm (Melissa officinalis) was planted in medium supplemented with 1-triacontanol at 2-10 ppb, shoot lengths increased significantly (Tantos et al., 1999). Significantly enhanced shoot growth was also observed in herbal plants, including coriander (Coriandrum sativum, Idrees et al., 2010), sweet basil (Ocimum basilicum, Hashmi et al., 2011), and Artemisia annua (Aftab et al., 2010) following treatments with foliar spray containing 1triacontanol at 439, 4.39, 43.9, and $1.5 \mathrm{ppm}$, respectively. In another study, seed germination of maize, paddy, and sunflower was significantly promoted by soaking in solution containing 1-10 ppm 1-triacontanol (Niranjana et al., 1999). In contrast, however, germination rates of seeds from 15 species, including soybean, lettuce (Lactuca sativa), and purslane (Portulaca oleracea), were not significantly enhanced when sown on absorbent paper in petri dishes containing 1-triacontanol at $4.39 \mathrm{ppm}$ (Hoagland, 1980).

Thus, the plant growth promotion effect of 1-triacontanol likely depends on concentration, treatment mode, and species. In this study, we demonstrated that boiled skins of Moso bamboo shoot hold sufficient concentrations of 1triacontanol to promote hypocotyl lengths of Welsh onion even after compost maturation. Further studies are required to determine volumes of Moso bamboo skins that are required to improve soils and promote growth or improve yields of agricultural plants such as Welsh onion.

More evidence is required to confirm that 1-triacontanol was responsible for increased growth of the present plants. Increased yields of vegetable or crop plants following application of boiled Moso bamboo skins will set a precedent, as shown with alfalfa plants (Ries et al., 1977a). Discarded biomass from bamboo shoot production in a village could be converted to local compost contributing to agricultural production within the same village. 


\section{CONCLUSIONS}

We isolated the main component of $n$-hexane extracts from fresh Moso bamboo shoot skins using silica-gel column chromatography and identified the plant growth regulator 1-triacontanol in NMR and EI-MS analyses. In our GCMS analyses, 1-triacontanol concentrations remained 19.7 ppm even after boiled skins were composted for 6 months. Our laboratory experiments show that 1triacontanol significantly promotes hypocotyl length of germinated Welsh onion. Thus, Moso bamboo shoot skins may provide functional compost that contains a plant growth regulator.

\section{ACKNOWLEDGEMENTS}

We thank Shojiro Oda (Life Design Co., Ltd., Fukuoka, Japan) and Takahiro Kazue (Kazue Bussan Inc., Fukuoka, Japan) for providing Moso bamboo shoot skins. The assistance of Akira Shima, Akihiro Tsutsumi, Michiyo Yamamoto, Mayumi Ikeda, Kuniko Okubo, and Yuri Uchida (Institute of Agricultural and Forest Resources, Fukuoka Agriculture and Forestry Research Center) in extracting from Moso bamboo shoot skins is greatly appreciated. We would like to thank Enago (www.enago.jp) for the English language review. Finally, the anonymous reviewers are gratefully acknowledged for valuable comments and suggestions.

\section{REFERENCES}

Aftab T, Khan MMA, Idrees M, Naeem M, Singh M, and Ram M. 2010. Stimulation of crop productivity, photosynthesis and artemisinin production in Artemisia annua L. by triacontanol and gibberellic acid application. Journal of Plant Interactions, 5:273-281.

Chen X, Yuan H, Chen R, Zhu L, Du B, Weng Q, and Heet G. 2002. Isolation and characterization of triacontanol-regulated genes in rice (Oryza sativa L.): Possible role of triacontanol as a plant growth stimulator. Plant and Cell Physiology, 43:869-876.

Chibnall AC, Piper SH, Pollard A, Smith JAB, and Williams EF. 1931. The wax constituents of the apple cuticle. Biochem Journal, 25:2095-2110.

Chibnall AC, Williams EF, Latner AL, and Piper SH. 1933. The isolation of $n$ triacontanol from lucerne wax. Biochem Journal, 27:1885-1888.

Chongtham N, Bisht MS, and Haorongbam S. 2011. Nutritional properties of bamboo shoots: Potential and prospects for utilization as a health food. Comprehensive Reviews in Food Science and Food Safety, 10:153-168.

Du S, Wang M, Zhu W, and Qin Z. 2009. A new fungicidal lactone from Xylocarpus granatum (Meliaceae). Natural Product Research, 23:13161321.

Forestry Agency, Ministry of Agriculture, Forestry and Fisheries, Japan 2020. A summary for demand and supply of main non-wood forest products in Japan fiscal year 2018. https://www.e-stat.go.jp/dbview?sid=0001784441. (accessed June 05, 2020) (In Japanese). 
Hagedorn O, Fleute-Schlachter I, Mainx HG, Zeisler-Diehl V, and Koch K. 2017. Surfactant-induced enhancement of droplet adhesion in superhydrophobic soybean (Glycine max L.) leaves. Beilstein Journal of Nanotechnology, 8:2345-2356.

Hashmi N, Khan MMA, Naeem M, Idrees M, Aftab T, and Moinuddin 2011. Ameliorative effect of triacontanol on the growth, photosynthetic pigments, enzyme activities and active constituents of essential oil of Ocimum basilicum L. Medicinal and Aromatic Plant Science Biotechnology, 5:2024.

Hoagland RE. 1980 Effects of triacontanol on seed germination and early growth. International Journal of Plant Sciences, 141:53-55.

Idrees M, Khan MMA, Aftab T, and Naeem M. 2010. Synergistic effects of gibberellic acid and triacontanol on growth, physiology, enzyme activities and essential oil content of Coriandrum sativum L. The Asian and Australasian Journal of Plant Science and Biotechnology, 4:24-29.

Iwamoto A, Mitsuda K, Inoue A, Kato T, Inoue Y, and Kawahara H. 2013. Purification and identification of an IgE suppressor from strawberry in an in vitro immunization system. Cytotechnology, 64:309-314.

Jackson MA, Eller FJ. 2006. Isolation of long-chain aliphatic alcohols from beeswax using lipase-catalyzed methanolysis in supercritical carbon dioxide. The Journal of Supercritical Fluids, 37:173-177.

Kolker LS. 1978. Analytical procedures for 1-triacontanol and its presence in plants and the environment. Dissertation, Michigan State University

Naeem M, Khan MMA, and Moinuddin 2012. Triacontanol: a potent plant growth regulator in agriculture. Journal of Plant Interactions,7:129-142.

Niranjana SR, Pandit A, Prakash HS, and Shetty HS. 1999. Effect of triacontanol on seed quality of maize, paddy and sunflower. Seed Science and Technology, 27: 1007-1013.

Olsson RA, Pearson JD. 1990. Cardiovascular purinoceptors. Physiological Reviews, 70:761-845.

Organization for Economic Co-operation and Development (OECD) 2006. Long chain alcohols (C6-22 primary aliphatic alcohols). SIDS (Screening Information Data Set) initial assessment report for SIAM (SIDS Initial Assessment Meeting) 22. Paris, France. 18-21 April.

Randrianasolo R, Krebs HC, Rakotoarimanga JV, Raharisolololao A, and Rakotondramanga M. 2015. Secondary metabolites of Phellolophium madagascariensis. Journal of Pharmacognosy and Phytochemistry, 4:5556.

Ries SK, Bittenbender H, Hangarter R, Kolker L, Morris G, and Wert V. 1977a. Improved growth and yield of crops from organic supplements. In: Lockeretz W (ed) Agriculture and Energy. Academic Press, New York, pp 377-384.

Ries SK, Wert V, Sweeley CC, and Leavitt RA. 1977b. Triacontanol: A new naturally occurring plant growth regulator. Science, 195:1339-1341. 
Ries SK. 1991. Triacontanol and its second messenger 9- $\beta-\mathrm{L}(+)-$ adenosine as plant growth substances. Plant Physiology, 95:986-989.

Ries S, SavithiryS, Wert V, and Widders I. 1993. Rapid induction of ion pulses in tomato, cucumber, and maize plants following a foliar application of $\mathrm{L}(+)-$ adenosine. Plant Physiology, 101:49-55.

Tanaka A, Kim HJ, Oda S, Shimizu K, and Kondo R. 2011. Antibacterial activity of moso bamboo shoot skin (Phyllostachys pubescens) against Staphylococcus aureus. Journal of Wood Science, 57:544-542.

Tanaka A. 2013. A search of bioactive substances from Moso bamboo. Master thesis, Kyushu University (in Japanese).

Tanaka A, Shimizu K, and Kondo R. 2013. Antibacterial compounds from shoot skins of moso bamboo (Phyllostachys pubescens). Journal of Wood Science, 59:155-159.

Tantos Á, Mészáros A, Kissimon J, Horváth G, and Farkas T. 1999. The effect of triacontanol on micropropagation of balm, Melissa officinalis L. Plant Cell Reports, 19:88-91.

Torii A, Isagi Y. 1997. Range expansion of bamboo species in southern areas of Kyoto prefecture, Japan. Japanese Journal of Ecology, 47:31-41. (in Japanese with English abstract)

Uchiyama T, Ogasawara N. 1981. Constituents of plant leaf waxes contained in rice callus tissues. Agricultural and Biological Chemistry, 45:1261-1263.

Upadhyay RK, Rohatgi L, Chaubey,MK, and Jain SC. 2006. Ovipositional responses of the pulse beetle, Bruchus chinensis (Coleoptera: Bruchidae) to extracts and compounds of Capparis decidua. Journal of Agricultural and Food Chemistry, 54:9747-9751. 